\title{
THE OCCURRENCE OF MICROCHARON IN THE PLYMOUTH OFFSHORE BOTTOM FAUNA, WITH DESCRIPTION OF A NEW SPECIES
}

\author{
By G. M. SPOONER \\ The Plymouth Laboratory \\ (With Text-figures I-2)
}

In September 1958, Prof. J. E. Harris, F.R.S., treated freshly collected Eddystone shell gravel with a magnesium sulphate solution and so produced a rich sample of the microfauna. This has never been adequately investigated, though the macrofauna is well known. The animals collected were mostly small Malacostraca, in which Amphipoda predominated, and Prof. Harris kindly passed on to me the whole sample to examine. I have found in it thirty-four species of amphipods, isopods, tanaids and cumaceans of which no fewer than fifteen are additions to the Plymouth fauna list (see Marine Biological Association, 1957). Some indeed are new to British waters, three or four being evidently undescribed species. One of the most striking of these is described here. The collection as a whole will be reported on later.

While the animals were mainly still living, Prof. Harris mentioned having noticed a small narrow pale form of unfamiliar appearance. Occasionally one came into his view revealing possession of fairly long antennae balanced, at the posterior end, by a pair of backwardly directed processes, dilated and more or less parallel-sided. The possible identity remained a puzzle until the preserved sample had been sorted. About twenty-five specimens were eventually picked out. Their body length ranged between $\mathrm{I} .0$ and $2.8 \mathrm{~mm}$., a size-range that included (above $\mathrm{I} .8 \mathrm{~mm}$ ) mature adults of both sexes. The structure of the pleon and its appendages showed them to be asellote isopods related to fanira. But they lacked eyes and pigment and (as shown by the few examples intact in this respect) possessed a most unusual development of the uropod, of which the peduncle was elongate and swollen. From these features they were readily identifiable as belonging to the blind subterranean genus Microcharon, as has been confirmed in detail.

\section{THE GENUS MICROCHARON}

In recent years various small aberrant crustaceans have been discovered living in subterranean ground water and interstitially in wet sand or gravel. Some of these (bathynellids, mystacocarids) belong to whole groups confined to this 
phreatic $^{1}$ realm, others (Stenasellus) are representative of normal freshwater families, or even, like the anthurid Microcerberus, of otherwise marine families. Microcharon Karaman, 1934, is one of a small group of genera which have such clear affinity to one or other of the marine Janiridae that they may well be included in that family (see Bocquet \& Lévi, 1955), though for a time a separate family Microparesellidae was erected for them. The species included in these genera are all small and blind and most of those known to date live in terrestrial underground freshwater habitats of one sort or another.

Microcharon itself was first discovered in the Skopolje district of Macedonia, where four species (M. stygius, M. latus, M. profundalis, M. major) are known. to date (Karaman, 1933, 1934, 1940, 1954). They occur well up into the mountain areas and subspeciation is already recognizable even within this territory. M. stygius has a subspecies hellenae in Greece. Another species, M. acherontis, is known from ground-water west of the Carpathians (Chappuis, I944), and another unnamed from Herzegovina (Karaman, 1953). Chappuis \& Delamare Deboutteville (1953) have reviewed the genus, adding M. sisyphus from ground-water in Corsica, and, of even greater interest, introducing two further species from coastal sand, showing that the genus extends into marine habitats. M. marinus was found in three localities on the southern coast of France and on the Italian coast south of Naples. M. teissieri (Lévi, 1950, as Duslenia) occurred in coarse marine sand dredged just below low-water mark off Roscoff. However, as Bocquet \& Lévi (1955) have pointed out, the occurrence in bottom deposits near the coast is not conclusive evidence that the species is truly marine, since its presence may depend on seepages of terrestrial ground water bringing with it its native fauna.

It is therefore of some interest to record a third species from the sea, living in a bottom deposit sufficiently far from the shore and occurring in such a geological setting that contamination with seeping ground-water from the land seems impossible.

\section{Microcharon harrisi sp.nov.}

This species is close to $M$. teissieri (Lévi) from coarse sand near Roscoff, as shown by the detailed structure of the mouthparts and other appendages. In particular, the form of male pleopod $\mathrm{I}$ is identical and pleopod 3 bears three plumed setae. The differences are seen in the larger size of harrisi, its relatively more elongate mesosome segments, its very distinctly longer antenna, and its somewhat more elongate pereiopods and uropod. M. teissieri has been well described and figured by Lévi (1950) and Chappuis \& Delamere Deboutteville (1953). Various details shared in common between the two species are not necessarily repeated below.

${ }^{1}$ A convenient (French phréatique) name for underground waters of all types, ranging from cave pools to interstices between coarse soil particles. 
The body length of adults (i.e. length excluding antennules, antennae and uropods) is $\mathrm{I} \cdot 8-2 \cdot 8 \mathrm{~mm}$, hence longer than other species except possibly M. major Karaman, and between $\mathrm{I} .5$ and 2.0 times the length of $M$. teissieri. The corresponding mean body width is $0.18-0.28 \mathrm{~mm}$, i.e. one-tenth of the length. (This assumes that no artificial pressure is applied, as by a coverslip on a mounted specimen. Also the loose intercalary connexions of the segments allow about a $\pm 15 \%$ expansion or contraction from the mean length.) Middle body segment about $85 \%$ the width of the head and pleotelson. See Fig. I A.

Head subrectangular, somewhat narrowed posteriorly, with mean dorsal length $I \cdot I$ to $\mathrm{I} \cdot 2$ times the central width; a short rounded prominence anteriorly between the antennae. No vestiges of eyes.

Pereion segments typically of proportions shown in Fig. I. Segment I about half length of head; segments 4 and 5 may be a little shorter than wide, the rest at least as long as wide, longer in the larger animals. (In M. teissieri all segments are described as shorter than wide.) There is a graded narrowing of mean width from both ends towards the middle, but only to an extent of about $10 \%$.

The separate first pleon segment is 0.4 to 0.6 the length of the last pereion segment. The pleotelson is usually about the same length as the head, but is distinctly longer in the larger individuals.

The antennula has five segments. This, with the mandible, maxilla and maxillipede of a $2.10 \mathrm{~mm}$ male are shown in Fig. 2. The antenna drawn is that of a $2.05 \mathrm{~mm}$ female; this limb is normally 3.2 to 3.4 times the length of the head, hence about twice as long (relatively) as described in M. teissieri, and furnishing the most obvious difference from that species (it is longer than the head + the first three mesosome segments). The squama on the third segment bears one or two long setae.

The pereiopods (Fig. 2E) are more elongate than in $M$. teissieri, though the difference is small in the younger adults.

The male pleopods (Fig. I B, Fig. 2 F, G, H) are as described for M. teissieri except that in pleopod 2 the distal region is shorter and less acute apically, conforming more nearly to the illustration of this limb in $M$. marinus Chappuis \& D. Deboutteville. Pleopod 3 (Figs. I C, $2 \mathrm{H}$ ) of both sexes bears three stout plumed setae, as does $M$. teissieri, but not any other known species.

The enlarged peduncle (sympode) of the uropod (Fig. IA, D) seems typically to be close to $\mathrm{I} \cdot 4$ times as long as the pleotelson ( $\mathrm{I} \cdot 5$ times in one male). This is relatively a little larger than in M. teissieri, M. marinus and $M$. major, and so is larger than in any of the species yet described. The endopodite is 0.30 to 0.33 the length of the peduncle, and the laterally directed exopodite is about half the length of the endopodite.

Females bear two eggs or young in the mesosomic ventral brood-pouch, as described in other species, and carry them up to the length of at least $0.85 \mathrm{~mm}$ (i.e. about half the body length of the mother).

Type locality: North of Eddystone Rock, in shell gravel, below depth of $23-28 \mathrm{fm}$. The site is 9 miles from the nearest point to the mainland.

Type specimens will be deposited in the British Museum.

Over seventy examples have now been examined. Only eight, however, of these retain one or both uropods, and only twenty-one possess one or other of the antennae. (The most complete specimen, the adult female figured, carried both uropods and one antenna.) The antennae easily break off at the end of the 4 th peduncle segment. Other limbs are not readily shed. This liability to lose the uropod and most of the antenna has been noted in other species, though $M$. teissieri is said to be much less liable to damage. 


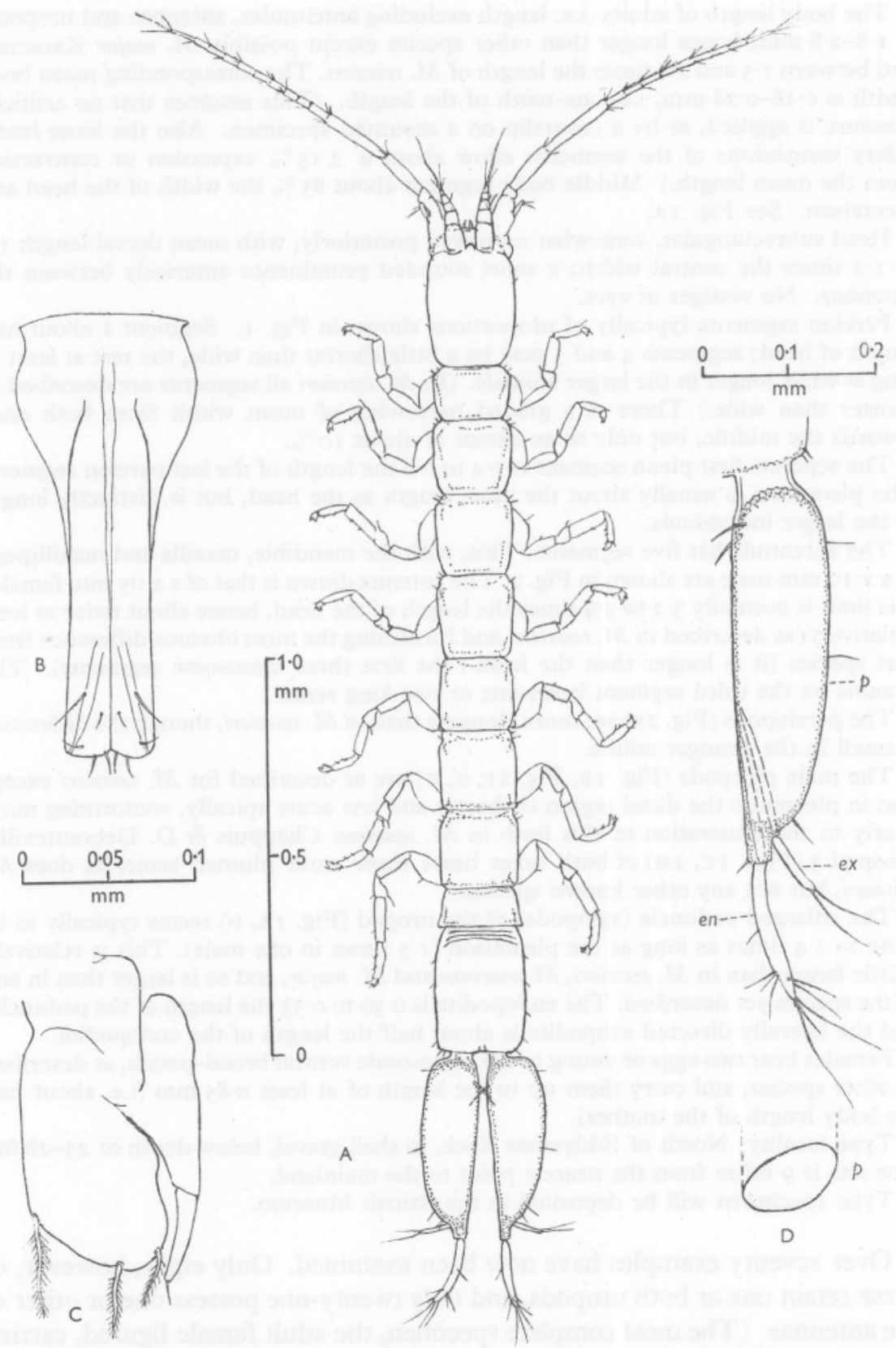

Fig. I. Microcharon harrisi sp.nov. A, adult female of $2.05 \mathrm{~mm}$ body length. B, pleopod I of male of $2.10 \mathrm{~mm}$. C, pleopod 3 of a female of ca. $2.3 \mathrm{~mm}$. D, uropod of male of $2.04 \mathrm{~mm}$, with section through middle given below, to show thickness: $p$, peduncle; $e x$, exopod; en, endopod. 


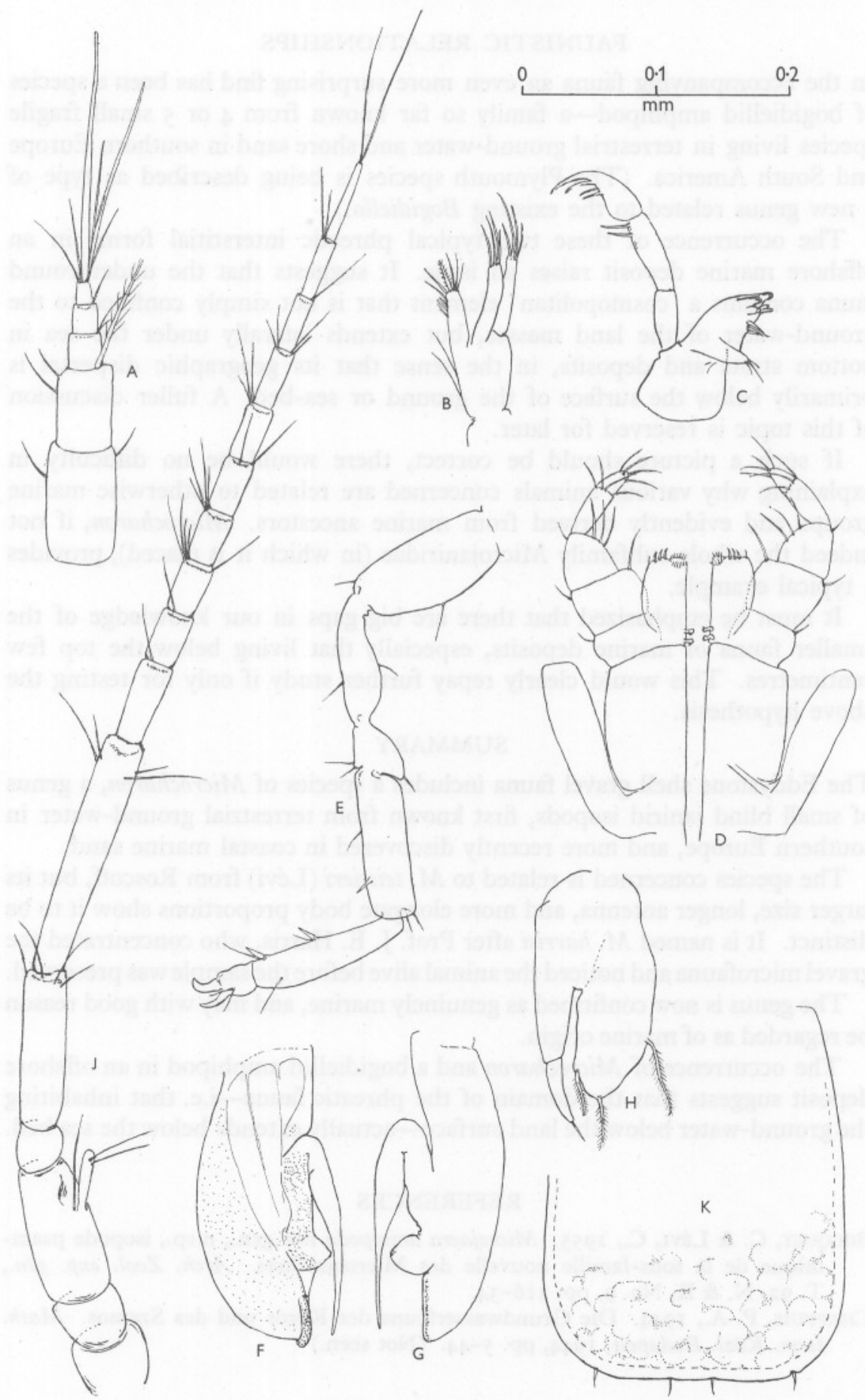

Fig. 2. Microcharon harrisi sp.nov. Limbs of male of $2 \cdot 10 \mathrm{~mm}$ : (A) antennula; (B) maxilla; (C) mandible; (D) maxillipede; (E) pereiopod 7; (F, G) pleopod 2, right and left from somewhat different angles; (H) pleopod 3. J, antenna of female of $2.05 \mathrm{~mm}$. $\mathrm{K}$, female operculum (fused pleopod I pair). 


\section{FAUNISTIC RELATIONSHIPS}

In the accompanying fauna an even more surprising find has been a species of bogidiellid amphipod-a family so far known from 4 or 5 small fragile species living in terrestrial ground-water and shore sand in southern Europe and South America. (The Plymouth species is being described as type of a new genus related to the existing Bogidiella.)

The occurrence of these two typical phreatic interstitial forms in an offshore marine deposit raises an issue. It suggests that the underground fauna contains a 'cosmopolitan' element that is not simply confined to the ground-water of the land masses, but extends laterally under the sea in bottom strata and deposits, in the sense that its geographic dispersal is primarily below the surface of the ground or sea-bed. A fuller discussion of this topic is reserved for later.

If such a picture should be correct, there would be no difficulty in explaining why various animals concerned are related to otherwise marine groups and evidently derived from marine ancestors. Microcharon, if not indeed the whole subfamily Microjaniridae (in which it is placed), provides a typical example.

It must be emphasized that there are big gaps in our knowledge of the smaller fauna of marine deposits, especially that living below the top few centimetres. This would clearly repay further study if only for testing the above hypothesis.

\section{SUMMARY}

The Eddystone shell gravel fauna includes a species of Microcharon, a genus of small blind janirid isopods, first known from terrestrial ground-water in southern Europe, and more recently discovered in coastal marine sand.

The species concerned is related to $M$. teissieri (Lévi) from Roscoff, but its larger size, longer antenna, and more elongate body proportions show it to be distinct. It is named $M$. harrisi after Prof. J. E. Harris, who concentrated the gravel microfauna and noticed the animal alive before the sample was preserved.

The genus is now confirmed as genuinely marine, and may with good reason be regarded as of marine origin.

The occurrence of Microcharon and a bogidiellid amphipod in an offshore deposit suggests that the domain of the phreatic fauna-i.e. that inhabiting the ground-water below the land surface-actually extends below the sea bed.

\section{REFERENCES}

BocQuet, C. \& LÉvi, C., I955. Microjaera anisopoda nov.gen., n.sp., isopode psammique de la sous-famille nouvelle des Microjanirinae. Arch. Zool. exp. gén., T. 92, N. \& R. No. 9, pp. 116-34.

Chappuis, P.-A., 1944. Die Grundwasserfauna der Körös und des Szamos. Math. term. Közl. Budapest, 1944, pp. 5-44. (Not seen.) 
Chappuis, P.-A. \& Delamere Deboutteville, C., 1953. Recherches sur les Crustacés souterrains. VII. Les Isopodes psammiques de la Méditerranée. Arch. Zool. exp. gén., T. 9I, Fasc. I, pp. 103-38.

KARAMAN, S., I933. Neue Isopoden aus unterirdischen Gewässern Jugoslaviens. Zool. Anz., Bd. 102, pp. 16-22.

— 1934. Beiträge zur Kenntnis der Isopodenfamilie Microparasellidae. Mitt. Höhlen $u$. Karstforsch., 1934, pp. 42-4. (Not seen.)

Karaman, S. 1940. Die unterirdischen Isopoden Südserbiens. Bull. Soc. Sci. Skoplje, T. 22. (Not seen.)

- 1953. Über subterrane Amphipoden und Isopoden des Karstes von Dubrovnik und seines Hinterlandes. Acta Mus. macedon. Sci. Nat., T. I, No. 7, pp. 137-67.

— 1954. Weitere Beiträge zur Kenntnis der microparaselliden Mazedoniens, das genus Microcharon Karaman. Fragmenta balcanica, T. I, No. I2, pp. I08-I4.

LÉvi, C., I950. Duslenia teissieri, nov.gen., n.sp., nouveau Parasellidé des côtes de France. Arch. Zool. exp. gén., T. 87, N. \& R., No. 5, pp. 42-7.

Marine Biological Association of U.K., 1957. Plymouth Marine Fauna. Third edition. 